Jurnal IImiah AL-Jauhari (JIAJ)

Volume 2 No 2, Desember 2017

ISSN: 2541-3430

E-ISSN: 2541-3449

Halaman 112-130

\title{
Studi Komparasi Konsep Pendidikan dalam Keluarga menurut Zakiah Daradjat dan Ki Hajar Dewantara
}

\author{
Herdiyanto Djafar \\ Email: herdiyanto.djafar@yahoo.co.id
}

\begin{abstract}
ABSTRAK
Tulisan ini melakukan suatu penyelidikan ilmiah untuk memperoleh gambaran tentang konsep pendidikan dalam keluarga antara Zakiah Daradjat dan Ki Hajar Dewantara dengan melihat penyebab-penyebabnya, sehingga dapat diperoleh persamaan dan perbedaannya terkait dengan generalisasi dari sekelompok fenomena tertentu dari pendidikan dalam rumah tangga sehingga dapat dipakai untuk menggambarkan berbagai fenomena yang sama. Tampaknya terdapat kesamaan dan perbedaan antara pemikiran Zakiah Daradjat dan Ki Hajar Dewantara. Persamaan dari keduanya adalah dari aspek tujuan pendidikan dan hakikat pendidikan dalam keluarga perbedaan dari keduanya adalah dari konsep pendidikan keluarga. Perbedaan dari pemikiran keduanya dari konsep pendidikan dalam keluarga dengan ciri khasnya yaitu konsep pendidikan Zakiah Daradjat memasukkan aspek nilai agama dalam konsep pendidikan keluarga. Sedangkan konsep pendidikan keluarga Ki Hajar Dewantara lebih banyak memasukkan unsur teori psikologis dalam pendidikan keluarga.
\end{abstract}

Kata Kunci: Pendidikan Keluarga, Zakiah Daradjat dan Ki Hajar Dewantara

\section{A. Pendahuluan}

Keluarga merupakan komponen masyarakat terkecil yang memiliki pengaruh dalam pendidikan yang ada di masyarakat. Karena keluarga adalah salah satu elemen pokok pembangunan entitas-entitas pendidikan, menciptakan prosesproses naturalisasi sosial, membentuk kepribadian-kepribadian, serta memberi berbagai kebiasaan baik pada anak-anak yang terus bertahan selamanya. ${ }^{1}$ Dengan kata lain, keluarga merupakan benih awal penyusunan individu dan struktur kepribadian. Dalam banyak kasus, anak-anak mengikuti orang tua dalam berbagai

\footnotetext{
${ }^{1}$ Baqir Syarif Al-Qarasi, Seni Mendidik Islami (Jakarta: Pustaka Zahra, 2003), h. 46.
} 
kebiasaan dan prilaku. Jadi orang tua sangat diperlukan peran aktifnya dalam mendidik anak-anaknya.

Setiap orang tua muslim mendambakan anak yang sholeh, dengan iman yang teguh, taat beribadah, dan akhlak terpuji. Tetapi untuk mewujudkan hal tersebut tidak semudah dibayangkan seperti membalikkan telapak tangan, melainkan harus melalui proses yang cukup panjang dan membutuhkan perjuangan. Meskipun dalam keadaan kepayahan, kesusahan, sebagai orang tua dalam mengasuh anaknya, tidak dapat mengikis kasih sayangnya kepada mereka. Harapan untuk memiliki anak sholeh tetap tertanam dalam hati kedua orang tua.

Keluarga merupakan tempat yang pertama dan utama membentuk kepribadian keagamaan, bahkan sampai kapan pun fungsinya tidak tergantikan oleh lembaga lainnya. Itulah sebabnya, kewajiban orang tua terhadap anaknya tidak hanya memenuhi kebutuhan lahiriah tetapi juga rohaniahnya berupa pendidikan agama.

Jadi baik dan buruk tumbuhnya anak merupakan tanggungjawab orang tua. Orang tua harus memperhatikan pendidikan anak sehingga kelak di akhirat dapat mempertanggungjawabkan amanat Allah. Keluarga sebagai lembaga pendidikan Islam mempunyai peranan penting membentuk generasi muda muslim. Keluarga adalah lembaga pendidikan informal, karena: Pendidikan informal, adalah pendidikan yang tidak diorganisasi secara struktural dan tidak mengenal sama sekali penjenjangan kronologis menurut tingkatan umum maupun tingkatan keterampilan dan pengetahuan. Persyaratan credentials tidak dipakai dan oleh karena itu tidak ada credentials yang dihakkan oleh penerima maupun yang diwajibkan dari pemberi pendidikan. ${ }^{2}$

Secara tersirat dipahami bahwa tujuan pendidikan dalam keluarga pada umumnya adalah agar anak menjadi pribadi yang mantap, beragama, bermoral, dan menjadi anggota masyarakat yang baik. Memperhatikan tujuan tersebut maka pendidikan keluarga dapat dipandang sebagai persiapan ke arah kehidupan anak dalam masyarakatnya. Adapun isi pendidikan dalam keluarga biasanya meliputi nilai agama, nilai budaya, nilai moral dan keterampilan. Sesuai dengan sifatnya (informal), keluarga tidak memiliki kurikulum formal tetapi mempunyai pengaruh terhadap pendidikan sekolah. ${ }^{3}$

Pendidikan agama di sekolah tidak akan berhasil bila pendidikan agama di rumah gagal. Bahkan menurut Ahmad Tafsir bahwa pendidikan agama di rumah merupakan kunci utama pendidikan agama di sekolah dan pendidikan di sekolah secara keseluruhan. Itulah sebabnya pendidikan agama dalam rumah tangga adalah pendidikan pertama dan utama. ${ }^{4}$

Dari uraian di atas jelaslah bahwa pendidikan keluarga meliputi yaitu: (1) Pendidikan Agama. Dasarnya adalah hakekat manusia bertuhan dan tujuan

${ }^{2}$ Soelaiman Joesoef dan Slamet Santoso, Pengantar Pendidikan Sosial (Surabaya: Usaha Nasional, 1981), h. 20.

${ }^{3}$ Dinn Wahyuddin, Pengantar Pendidikan (Modul 1-9) (Jakarta: Universitas Terbuka, Cet. I, 2007), h. 3.7.

${ }^{4}$ Ahmad Tafsir, Ilmu Pendidikan dalam Perspektif Islam (Bandung: Remaja Rosdakarya, 2005), h. 158. 
pendidikan agama ialah membentuk manusia yang taat. Pembentukan manusia ini mencakup tiga hal adalah: pembentukan kesadaran, pengetahuan agama; pembentukan sikap mental positif terhadap agama; pembentukan perbuatan religius. (2) Pendidikan Moral. Dasarnya adalah hakikat manusia sebagai makhluk ethis, yaitu makhluk yang dapat menyadari norma dan mampu berbuat sesuai norma. Pendidikan moral ini disebut juga pembentukan karakter. (3) Pendidikan keterampilan sebagai bekal untuk melaksanakan kehidupannya terkait dengan skill berupa kemampuan di bidang teknis dan prosedural tentang sesuatu.

Untuk itulah sangat menjadi dasar yang kokoh dari kedua aspek tadi yaitu lembaga fomal dan informal berjalan beriringan untuk memacu secara bersama dalam melahirkan fenomena-fenomena baru guna mencapai keterpaduan yang lebih matang terutama dalam menuntaskan pembelajaran pendidikan agama Islam bagi peserta didik. Ketuntasan berarti tercapainya tujuan pembelajaran pendidikan agama Islam secara optimal sesuai dengan yang diharapkan.

Pendidikan berusaha mengubah keadaan seseorang dari tidak tahu menjadi tahu, dari tidak dapat berbuat menjadi dapat berbuat, atau dari tidak bersikap seperti yang diharapkan menjadi bersikap seperti yang diharapkan. Di samping itu, kegiatan pendidikan adalah usaha membentuk manusia secara keseluruhan, utuh, lengkap dan terpadu aspek kemanusiaannya. Secara umum dan ringkas dapat dikatakan bahwa pendidikan merupakan usaha pembentukan kepribadian manusia. Pendidikan informal adalah salah satu jalur pendidikan yang perlu mendapat perhatian untuk mewujudkan tujuan pendidikan.

Salah satu fungsi keluarga adalah melaksanakan pendidikan terutama pendidikan agama. Dalam hal ini orang tua orang tua (ayah dan ibu) adalah pengemban tanggungjawab pendidikan anak. Tidak ada anak yang baru lahir sudah tahu seluk beluk agama dan ilmunya, tahu tentang iman dan keyakinan. Semua anak lahir dalam keadaan polos total. ${ }^{5}$

Pendidikan dalam keluarga dilaksanakan atas dasar tanggungjawab kodrati dan atas dasar kasih sayang yang secara naluriah muncul pada diri orang tua. Keluarga menurutnya merupakan lingkungan dan lembaga pertama yang dikenal oleh seorang anak. Lembaga pendidikan tertua ini mempunyai peran yang sangat besar dalam membentuk kepribadian anak. Interaksi anak dengan lingkungan pertamanya sangat berpengaruh terhadap jiwa, kebiasaan dan emosi dari anak itu. Individu tidak akan bisa bersosialisasi dengan lingkungan lainnya tanpa adanya lingkungan keluarga. ${ }^{6}$

Dari keluarga, anak belajar mengenal orang lain dan dirinya sendiri, yaitu belajar menanamkan kasih sayang dan saling menghargai. Karena itu, Nahlawi menegaskan bahwa pendidikan orang tua terhadap anak adalah pendidikan didasarkan pada rasa kasih sayang terhadap aanak dan yang diterimanya dari

\footnotetext{
${ }^{5}$ Muhaimin, Tema-Tema Pokok Dakwah Islam di Tengah Transformasi Sosial (Surabaya: Karya Abditama, t.th.), h. 70.

${ }^{6}$ Dinn Wahyuddin, op.cit., h. 3.6.
} 
kodrat. ${ }^{7}$ Orang tua adalah pendidik sejati, pendidik karena kodratnya. Jadi kasih sayang orang tua terhadap anak hendaklah kasih sayang sejati.

Pendidikan berdasarkan kasih sayang saja kadang-kadang mendatangkan bahaya. Kasih sayang harus dijaga jangan sampai berubah menjadi memanjakan anak. Kasih sayang harus dilengkapi dengan pandangan yang sehat tentang sikap kita terhadap anak. Pengalaman diterima anak semasa kecil akan menentukan sikap hidupnya di kemudian hari. Sehubungan dengan itu keluarga dalam hal ini orang tua merupakan peletak dasar pendidikan anak. ${ }^{8}$

Di dalam keluarga, orang tua berperan di samping sebagai bapak dan ibu yang harus mengayomi anak-anaknya juga sebagai pendidik non struktural. Orang tua menjadi rujukan moral, sosial dan spiritual utama anak-anaknya sehingga keteladanan dari orang tua sangat ditekankan. Keteladanan menjadi faktor penting dalam hal baik buruknya anak. ${ }^{9}$

Orang tua dituntut untuk bertingkah laku yang baik dalam kehidupan sehari-hari serta mampu menempatkan dirinya dalam posisi panutan, pemberi contoh dan model yang baik bukan saja dalam ibadah seperti sholat dan puasa tetapi juga dan ini yang terpenting adalah menjadi rujukan moral bagi anakanaknya yang bisa di pertanggungjawabkan. ${ }^{10}$

Ditilik dari hubungan dan tanggung jawab orang tua terhadap anak, maka tanggung jawab pendidikan itu pada dasarnya tidak bisa dipikulkan kepada orang lain, sebab guru dan pemimpin umat umpamanya dalam memikul tanggung jawab pendidikan hanyalah merupakan keikutsertaan. Dengan kata lain tanggung jawab pendidikan yang dipikul oleh para pendidik selain orang tua merupakan pelimpahan dari tanggung jawab orang tua yang karena satu dan lain hal tidak mungkin melaksanakan pendidikan anaknya secara sempurna.

Pada dasarnya fungsi keluarga yang besifat universal adalah: (a) Sebagai pranata yang membenarkan hubungan seksual antara pria dan wanita dewasa berdasarkan pernikahan. (b) Mengembangkan keturunan (c) Melaksanakan keturunan dan (d) Sebagai kesatuan ekonomi ${ }^{11}$

Dengan memperhatikan uraian di atas, jelaslah bahwa sungguh luas dan besar tanggungjawab orang tua itu terhadap pendidikan anak meliputi kehidupan dunia akhirat, sehingga tidaklah mungkin orang tua dapat memikul sendiri secara penuh dan sempurna, lebih-lebih dalam masyarakat yang senantiasa berkembang maju. Hal ini bukanlah merupakan aib karena tanggung jawab tersebut tidaklah sepenuhnya dipikul oleh orang tua secara sendiri-sendiri, sebab mereka, sebagai manusia mempunyai keterbatasan-keterbatasan. Akan tetapi patutlah diingat

${ }^{7}$ Abdurrahman an-Nahlawi, Pendidikan Islam di Rumah, Sekolah dan Masyarakat (Terj. Shihabuddin) (Jakarta: Gema Insani Press, 2000), h. 140

${ }^{8}$ Dinn Wahyuddin, op.cit.., h. 3.7

${ }^{9}$ Abdullah Nahih Ulwan, Pedoman Pendidikan Anak dalam Islam (terj. Saifullah Kamalie) (Semarang: Asy-Syifa, 2001), h. 2

${ }^{10}$ Harun Nasution, Islam Rasional; Gagasan dan Pemikiran (Bandung: Mizan, 2001), h.446.

${ }^{11}$ Ibid., h. 38 . 
bahwa setiap orang tua tidak dapat mengelak dari tanggung jawab tersebut, artinya, pada akhirnya, betapa pun juga, tanggung jawab pendidikan itu tetap menjadi tanggung jawab orang tua.

Dari latar belakang masalah yang penulis uraikan di atas, yakni arti pentingnya pendidkan keluarga bagi umat manusia sekaligus juga pemikiran dan metode dari kedua tokoh pendidikan dalam kajian tesis ini dalam mamahami tentang pentingnya pendidikan keluarga, penelitian dalam penyusunan tesis ini penulis harapkan bisa memperoleh gambaran yang jelas serta persamaan dan perbedaan pemikiran kedua tokoh tersebut terutama berkaitan dengan tujuan, materi dan metode.

\section{B. Riwayat Hidup Zakiah Daradjat dan Ki Hajar Dewantara}

\section{Riwayat hidup Zakiah Daradjat}

Zakiah Daradjat dilahirkan di ranah Minang, tepatnya di kampung Kota Merapak, kecamatan Ampek Angkek, Bukit Tinggi, pada tanggal 6 November 1929. Anak sulung dari pasangan suami istri Daradjat ibn Husein, bergelar Raja Ameh (Raja Emas) dan Rapi'ah binti Abdul Karim, sejak kecil tidak hanya dikenal rajin beribadah, tetapi juga tekun belajar. Ia wafat saat dirawat di rumah sakit UIN Syarif Hidayatullah Jakarta pada hari Selasa 15 Januari 2013 sekitar pukul 09.00 wib. Zakiah Daradjat sempat mengalami kritis dalan menjalani perawatan di RS Hermina, Jakarta Selatan, pertengahan Desember 2012, Zakiah Daradjat dimakamkan di komplek UIN Ciputat. Menjelang akhir hayatnya, ia masih aktif mengajar, memberikan ceramah, dan membuka konsultasi psikologi. Sebelum meninggal, sempat menjalani perawatan di Rumah Sakit Hermina, Jakarta Selatan pada pertengahan Desember 2012.

Pada usia enam tahun, Zakiah sudah mulai memasuki sekolah. Pagi belajar di Standaardshool (Sekolah Dasar) Muhammadiyah, sementara sorenya mengikuti sekolah Diniyah kemudian melanjutkan ke Kulliyatul Muballighat di Padang Panjang. Seperti halnya ketika duduk di sekolah dasar, sore harinya Zakiah juga mengikuti kursus di SMP. Namun, pada saat duduk di bangku SMA, hal yang sama tidak bisa lagi dilakukannya karena lokasi SMA jauh dari kampungnya, yaitu di Bukit Tinggi. Pada tahun 1951, setelah menamatkan SMA, Zakiah meninggalkan kampung halamannya untuk melanjutkan studi ke Yogyakarta di fakultas Tarbiyah Perguruan Tinggi Agama Islam Negeri (PTAIN). Di samping di PTAIN Zakiah juga kuliah di fakultas Hukum Universitas Islam Indonesia (UII). Akan tetapi, Kuliahnya di UII harus berhenti di tengah jalan. ${ }^{12}$ Kemudian pada tahun 1956, Zakiah bertolak ke Mesir dan langsung diterima (tanpa tes) di Fakultas Pendidikan Universitas Ein Shams, Kairo, untuk program $\mathrm{S} 2$. $^{13}$

Setelah meraih MA selanjutnya menempuh program S3 di universitas yang sama. Ketika menempuh program S3 kesibukan Zakiah tidak hanya belajar. Pada tahun 1964, dengan disertasi tentang perawatan jiwa anak, Zakiah berhasil

\footnotetext{
${ }^{12}$ Ibid., h. 6.

${ }^{13}$ Badri Yatim, dkk., op.cit., h. 6.
} 
meraih gelar doktor dalam bidang Psikologi dengan spesialisasi kesehatan mental dari universitas Ein Shams. ${ }^{14}$

\section{Riwayat hidup Ki Hajar Dewantara}

Raden Mas Suwardi Suryanigrat dikenal sebagai tokoh pendidikan nasional dan tokoh persuratkabaran pada masa pergerakan nasional. saat genap berusia 40 tahun menurut hitungan Tahun Caka, berganti nama menjadi Ki Hadjar Dewantara. Semenjak saat itu, ia tidak lagi menggunakan gelar kebangsawanan di depan namanya. Hal ini dimaksudkan supaya ia dapat bebas dekat dengan rakyat, baik secara fisik maupun hatinya. ${ }^{15}$ Beliau merupakan sosok pribadi yang tegar, kuat, dan bersahaja. Suwardi Suryanigrat selalu membela kepentingan rakyat Indonesia. Beliau dilahirkan di Yogyakarta pada hari kamis lega, tanggal 2 Mei 1899. Beliau merupakan bangsawan dari Keraton Pakualaman Yogyakarta karena ayahnya bernama Soeryaningrat merupakan putra Pakualam III. ${ }^{16}$ Tokoh pergerakan nasional yang berjuang melalui pers dan pendidikan ini meninggal dunia tanggal 26 April 1959 dan dimakamkan di Wijayabrata, Yogyakarta. Hari kelahiran Ki Hajar Dewantara, tanggal 2 Mei juga ditetapkan oleh pemerintah sebagai Hari Pendidikan Nasional.

Semasa kecil, Suwardi Suryaningrat sekolah di Europesche Lagere School yang merupakan sekolah rendah Belanda. Beliau merupakan keturunan bangsawan sehingga beliau dengan mudah bersekolah di sekolah Belanda. Kemudian Suwardi Suryanigrat melanjutkan pendidikan di Kweekschool (sekolah guru), namun belum sempat selesai, Beliau pindah ke sekolah dokter pribumi (STOVIA). Dikarenakan kekurangan biaya, Suwardi Suryaningrat tidak selesai studinya. Setelah keluar dari STOVIA, Suwardi Suryanigrat terjun ke bidang jurnalistik. Suwardi Suryanigrat memperdalam ilmu pendidikan, Beliau belajar ilmu pendidikan modern dari Dr. Maria Montessori dan Jan Lichthart, tokoh pendidikan modern Belanda. Pada tahun 1916, Suwardi Suryanigrat berhasil memperoleh gelar ijasah bidang pendidikan. ${ }^{17}$

\section{Persamaan Pendidikan Keluarga Zakiah Daradjat dengan Ki Hajar Dewantara}

Jika dicermati terdapat persamaan pandangan antara pendidikan keluarga Zakiah Daradjat dengan Ki Hajar Dewantara yakni dilihat dari pentingnya pendidikan keluarga bagi individu terutama bagi kehidupan anak. Pada dasarnya keluarga merupakan lingkungan pendidikan yang pertama dan utama. Pertama karena anak pertama kalinya mendapatkan arahan dan bimbingan dari keluarga atau orang tua. Utamanya karena sebagian besar dari kehidupan anak adalah di dalam keluarga.

\footnotetext{
${ }^{14}$ Ibid., h. 9.

${ }^{15}$ Hasbullah, Dasar-Dasar Ilmu Pendidikan (Jakarta: Raja Grafindo Persada, 2009), h. 266.

${ }^{16}$ Enny Sukasih, Tokoh-tokoh Pergerakan Nasional (Surakarta: Mediaatama, 2008), h. 13.

${ }^{17}$ Enny Sukasih, op.cit., h. 14.
} 
Tugas utama dari keluarga bagi pendidikan anak adalah merupakan peletak dasar bagi pendidikan akhlak dan pandangan hidup keagamaan. Sifat dan tabiat anak sebagian besar diambil dari kedua orang tuanya dan dari anggota keluarga yang lain. ${ }^{18}$

Tanggung jawab kepala keluarga untuk membuat anaknya berakhlak mulia sangat besar. Anak semasa kecil tidak mengetahui apa-apa, bagaikan kertas putih tanpa tulisan, bersih tanpa noda. Tergantung bagaimana orang tua mengajarkan kepada anak akhlak-akhlak yang mulia, sehingga anak bisa mandiri.

Sebagai penanggungjawab yang pertama dan utama, orang tua harus melakukan bimbingan dan bantuan kepada anaknya. Pada prisipnya bantuan tersebut masih dalam tahab yang wajar sebagaimana orang tua pada anaknya, yaitu yang kodrati. Orang tua masih bertanggung jawab dan wajib membimbing anaknya dari anak lahir sampai anak tumbuh dewasa, dalam artian sudah menikah atau berkeluarga. Walaupun secara fisik anak sudah bisa dilepas oleh orang tuanya, akan tetapi secara batin, moral tetap terjalin.

Agar anak mampu berkembang secara maksimal, meliputi seluruh aspek perkembangan anak, yaitu aspek jasmani, akal, dan rohani.

1. Tanggung jawab yang berkenaan dengan jasmani. Anak harus diperhatikan kesehatan dan kekuatan badan serta keterampilan otot. Orang tua menanamkan dan membiasakan hidup sehat, dengan cara memberikan contoh hidup sehat, keteraturan dalam kehidupan. Dalam hal ini harus dilakukan sedini mungkin. ${ }^{19}$

2. Tanggung jawab yang berkenaan dengan akal. Orang tua harus membimbing anaknya supaya mempunyai kecerdasan, ilmu pengetahuan serta kemampuan berfikir. Untuk itu maka orang tua harus memerlukan bantuan dari luar.

3. Tanggung jawab yang berkenaan dengan rohani. Tanggung jawab rohaniah juga tanggung jawab yang tidak kalah pentingnya dengan tanggung jawab yang lainnya.

Melihat banyak sekali tugas atau tanggung jawab yang dibebankan kepada orang tua, maka dapat diperkirakan bahwa orang tua tidak dapat memikul sendiri secara "sempurna" lebih-lebih dalam masyarakat yang senantiasa berkembang maju. Namun, bagaimanapun juga manusia mempunyai keterbatasan-keterbatasan dalam menjalankan semua itu dan sangat membutuhkan bantuan dari orang lain (pendidik atau orang tua). ${ }^{20}$

Selain hal di atas, dasar-dasar tanggung jawab orang tua terhadap pendidikan anaknya meliputi: (a) Adanya motivasi atau dorongan cinta kasih yang menjiwai hubungan orang tua dengan anak. (b) Pemberian motivasi kewajiban moral sebagai konsekuensi kedudukan orang tua terhadap keturunannya. Adanya tanggung jawab moral ini meliputi nilai-nilai agama atau nilai-nilai spiritual. (c) Tanggung jawab sosial adalah bagian dari keluarga yang pada gilirannya akan

\footnotetext{
${ }^{18}$ Hasbullah, op.cit., h. 38.

${ }^{19}$ Tim dosen Fakultas Tarbiyah IAIN Sunan Ampel Malang, Dasar-Dasar Pendidikan Islam: Suatu Pengantar Ilmu Pendidikan Islam, Surabaya: Karya Aditama, 1996, hal. 183

${ }^{20}$ Zakiah Darajat, op-cit., h. 39
} 
menjadi tanggung jawab masyarakat, bangsa dan negara. (d) Memelihara dan membesarkan anaknya. Tanggung jawab ini merupakan dorongan yang alami untuk dilaksanakan. (e) Memberikan pendidikan dengan berbagai ilmu pengetahuan dan keterampilan yang berguna bagi kehidupan anak kelak. ${ }^{21}$

Jadi, tanggung jawab yang dipikul oleh orang tua tidak dapat dielakkan lagi. Kesadaran akan tanggung jawab mendidik dan membina anak perlu dikembangkan lagi. Mengingat akan kemajuan zaman sekarang ini, maka kiranya orang tua juga bisa mendidik sesuai dengan perkembangan zaman, tentunya masih berdasarkan pada syariat Islam. Apalagi mengenai pendidikan, maka orang tua tidak mendidik anak berdasarkan kebiasaan saja, akan tetapi pada teori-teori pendidikan yang berkembang.

Ki Hadjar Dewantara mengatakan, pendidikan keluarga adalah suatu tempat yang sebaik-baiknya untuk melakukan pendidikan sosial juga, sehingga dapat dikatakan, bahwa keluarga itulah tempat penidikan yang lebih sempurna sifat dan wujudnya dari pada pusat pendidikn lain-lainnya, untuk melangsungkan pendidikan kearah kecerdasan budi pekerti (pembentukan watak individual) dan sebagai persedian hidup dimasarakat. ${ }^{22}$

Pada umumnya pendidikan dalam rumah tangga bukan berpangkal tolak dari kesadaran dan pengertian yang lahir dari pengetahuan mendidik, melainkan karena secara kodrati suasana dan strukturnya memberikan kemungkinan alami membangun situasi pendidikan. Situasi pendidikan ini terwujud berkat adanya pergaulan dan hubungan pengaruh mempengaruhi secara timbal balik antara orang tua dan anak didik",23.

Tidak diragukan, keluarga memiliki dampak yang besar dalam pembentukan prilaku individu serta pembangunan vitalitas dan ketenangan dalam benak anak-anak. Melalui keluarga, anak-anak mendapatkan bahasa, nilai-nilai serta kecenderungan mereka. Keluarga menyumbang secara langsung pada pembangunan peradaban umat manusia dan hubungan asosiatif diantara orangorang. Ia membawa anak-anak untuk belajar prinsip-prinsip sosiologi serta kaidah etika dan moralitas.

Dalam keluarga anak mendapatkan rangsangan, hambatan atau pengaruh yang pertama dalam pertumbuhan dan perkembangannya, baik itu perkembangan biologis maupun perkembangan kepribadiannya. Dalam keluarga pula anak mengenal dan mempelajari norma-norma dan aturan-aturan permainan dalam hidup bermasyarakat.

Lembaga pendidikan keluarga memberikan pengalaman pertama merupakan faktor penting dalam perkembangan pribadi anak. Para ahli ilmu jiwa sangat menekankan pentingnya penghidupan keluarga, sebab pengalaman masa anak-anak yang menyakitkan meskipun sudah jauh terpendam di masa silam, tetap dapat mengganggu keseimbangan jiwa di dalam perkembangan individu selanjutnya.

\footnotetext{
${ }^{21}$ Hasbullah, op-cit., h. 44-45

${ }^{22}$ Ki Hadjar Dewantara, Pendidikan, karya bagian I (Yogyakarta: TS, 1977) h. 374

${ }^{23}$ Zakiah Daradjat, Ilmu Pendidikan Islam (Jakarta: Bumi Angkasa, 1996), h. 35
} 
Menurut Zakiah Daradjat, keluarga merupakan salah satu tripusat pendidikan, pendidikan keluarga merupakan pusat pendidikan yang terpenting karena pengaruh hidup itu terus menerus dialami oleh anak-anak. Keluarga juga merupakan lingkungan yang pertama bagi anak, di lingkungan kelurga pertama mendapatkan pengaruh, karena itu keluarga merupakan lembaga pendidikan tertua, yang bersifat informal dan kodrati. ${ }^{24}$

Melalui kehidupan keluarga, aspek emosional, moral, sosial anak dan kebutuhan akan rasa kasih sayang dapat dipenuhi atau berkembang dengan baik, hal ini disebabkan karena adanya hubungan darah antara pendidik dan anak didik. Keluarga tidak hanya sebagai persekutuan hidup antara orang tua dan anak, tetapi juga tempat anak memperoleh pendidikan terutama pendidikan agama.

Dari uraian di atas, telah disimpulkan bahwa keluarga adalah suatu kelompok kecil dalam masyarakat yang terdiri dari ayah (suami), ibu (istri) dan anak, meskipun kadang-kadang dalam keluarga itu juga terdapat kakek, nenek, paman, bibi dan sebagainya serta terdiri dari unsur-unsur antara lain yaitu lahir dari hasil perkawinan atau adopsi. Setiap anggota memiliki hak dan kewajiban secara timbal balik dan memiliki fungsi utama terutama pada anak-anak.

Menurut Zakiah Daradjat pada umumnya pendidikan dalam keluarga itu bukan berpangkal tolak dari kesadaran dan pengertian yang lahir dari pengetahuan, melainkan secara kodrati suasana dan strukturnya memberikan kemungkinan alami membangun situasi pendidikan. Situasi pendidikan itu terwujud berkat adanya kebiasaan yang diberikan keluarga kepada anaknya secara terus menerus sehingga tertanam dalam jiwa anak.

Secara lebih tegas dikemukakan oleh Zakiah Daradjat bahwa tujuan pendidikan dalam Islam termasuk dalam pendidikan keluarga atau rumah tangga secara garis besarnya adalah untuk membina manusia agar menjadi hamba Allah yang saleh dengan seluruh aspek kehidupannya, perbuatan, pikiran, dan perasaanya. $^{25}$

Di dalam lingkungan keluarga merupakan lingkungan pendidikan yang pertama dan utama, karena dalam keluarga inilah anak mendapatkan pendidikan dan bimbingan. Di samping itu keluarga merupakan wadah pertama dan utama bagi pertumbuhan dan perkembangan anak. Jika suasana dalam keluarga itu baik dan menyenangkan, maka anak akan tumbuh dengan baik pula. Jika tidak, tentu akan terhambatlah pertumbuhan anak tersebut. ${ }^{26}$

Keluarga berperan sebagai pengarah yang dapat dilakukan sendiri, pertama-tama untuk mendorong bakat yang baru muncul, kemudian orang tua mencarikan guru yang baik untuk anaknya. Selain itu untuk menangani anak yang sedang mengembangkan bakatnya, maka keluarga harus terus menerus

${ }^{24}$ Nur Ahid, Pendidikan Keluarga dalam Perspektif Islam (Yogyakarta: Pustaka Pelajar, 2010), h.99.

${ }^{25}$ Zakiah Darajat, Pendidikan Islam dalam Keluarga dan Sekolah (Jakarta: Ruhama, 1995), h. 35 .

${ }^{26}$ Ibid., h. 47. 
mendorong semangatnya dan menegur kelalaiannya apabila berteman dengan anak yang kurang baik.

Ki Hadjar Dewantara berpendapat bahwa pendidikan keluarga adalah suatu tempat yang sebaik-baiknya untuk melakukan pendidikan sosial juga, sehingga dapat dikatakan bahwa keluarga itulah tempat pendidikan yang lebih sempurna sifat dan wujudnya dari pada pusat pendidikan lain-lainnya, untuk melangsungkan pendidikan kearah kecerdasan budi pekerti (pembentukan watak individual) dan sebagai persediaan hidup kemasarakat.

Ki Hajar Dewantara dalam konsep pendidikannya mengarahkan pada uapa menanamkan jiwa merdeka bagi rakyat melalui bidang pendidikan termasuk dalam lingkungan keluarga. Namun telah diakui dunia bahwa kecerdasan, keteladanan, dan kepemimpinan telah menghantarkannya sebagai seorang yang berhasil meletakkan dasar pendidikan nasional Indonesia. Jika dikaitkan dengan pendidikan Islam, maka dapat ditegaskan bahwa Ki Hajar Dewantara mengajak masyarakat untuk meningkatkan pendidikan agar nantinya dapat mendapatkan kecerdasan, keteladanan serta merasakan hidup bahagia di dunia dan di akhirat. Penelitian ini diharapkan akan menjadi bahan informasi dan masukan bagi mahasiswa, orang tua, tenaga pengajar, para peneliti, dan semua pihak yang membutuhkan.

Jika dicermati tampaknya antara Zakiah Daradjat dan Ki Hajar Dewantara memiliki persamaan pandangan tentang kedudukan pendidikan keluarga sebagai pusat pendidikan bagi anak. Menurut Zakiah Daradjat bahwa keluarga merupakan lingkungan pendidikan yang pertama dan utama, karena dalam keluarga inilah anak mendapatkan pendidikan dan bimbingan. Di samping itu keluarga merupakan wadah pertama dan utama bagi pertumbuhan dan perkembangan anak. Sama halnya dengan Ki Hajar Dewantara yang memposisikan keluarga sebagai pusat pendidikan, yang berarti menuntut adanya berbagai pendidikan baik pendidikan individual maupun pendidikan sosial bagi anak dilakukan dalam lingkungan keluarga. Sedangkan lembaga pendidikan lain berfungsi sebagai pelengkap dan pendorong bagi jalannya pendidikan keluarga.

\section{Perbedaan Pendidikan Keluarga Zakiah Daradjat dan Ki Hajar Dewantara}

Perbedaan mendasar pendidikan keluarga antara Zakiah Daradjat dan Ki Hajar Dewantara adalah pada sumber pemikirannya yang satu mendasarkan pada al-Qur'an dan Hadis sedangkan Ki Hajar Dewantara lebih banyak memberikan pemikiran dengan mendasarkan pada budaya dan logika sedangkan Zakiah Daradjat menekankan pada pendidikan agama.

Sebagaimana ditegaskan oleh Zakiah Daradjat bahwa dasar pelaksanaan pendidikan agama Islam adalah Al-Qur'an dan Sunnah Nabi Muhammad SAW yang dapat dikembangkan dengan Ijtihad, Al-Maslahah Al-Mursalah, Istihsan, Qias dan sebagainya. ${ }^{27}$ Dasar pelaksanaan pendidikan agama Islam sama dengan dasar pendidikan agama yang kedua yaitu dasar religius. Oleh karena itu penulis

${ }^{27}$ Zakiah Darajat, Ilmu Pendidikan Islam (Jakarta: Bumi Aksara, 1996), h. 19. 
akan menjabarkan dasar pelaksanaan pendidikan agama yang di dalamnya di khususkan pada pendidikan agama Islam.

Dasar Al-Qur'an adalah Firman Allah SWT. berupa wahyu yang disampaikan oleh Jibril kepada Nabi Muhammad SAW. Di dalamnya terkandung ajaran pokok yang dapat dikembangkan untuk keperluan seluruh aspek kehidupan melalui Ijtihad. Agama yang terkandung dalam Al-Qur'an itu terdiri dari dua prinsip besar yaitu yang berhubungan dengan masalah keimanan yang disebut aqidah dan yang berhubungan dengan amal yang disebut syari'ah.

Ajaran-ajaran yang berkenaan dengan iman tidak banyak dibicarakan dalam Al-Qur'an dan tidak sebanyak ajaran yang berkenaan dengan amal perbuatan. Itu artinya bahwa amal itulah yang paling banyak dilaksanakan sebab amal perbuatan manusia dalam hubungannya dengan Allah, dengan alam, lingkungannya dan dengan makhluk lain termasuk dalam ruang lingkup amal saleh (syari'ah). Istilah-istilah yang biasa digunakan dalam membicarakan ilmu tentang syari'ah ini ialah: Ibadah, Mu'amalah dan Akhlak. ${ }^{28}$ Menurut ajaran Islam, melaksanakan pendidikan agama merupakan perintah dari Tuhan dan merupakan ibadah kepada-Nya. Ayat yang menunjukkan adanya perintah tersebut adalah Surat An-Nahl ayat 125:

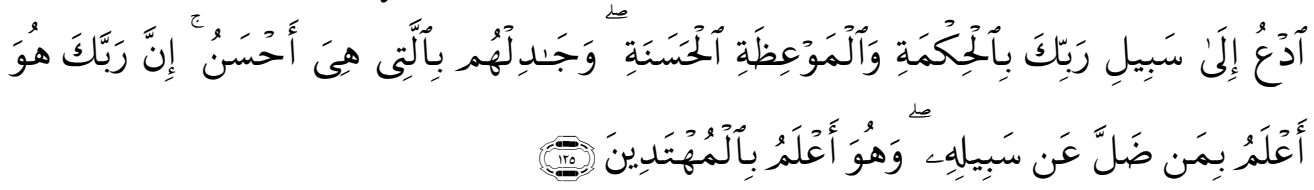

Terjemahnya:

Serulah (manusia) kepada jalan Tuhanmu dengan hikmah dan pelajaran yang baik dan bantahlah mereka dengan cara yang baik. Sesungguhnya Tuhanmu Dialah yang lebih mengetahui tentang siapa yang tersesat dari jalan-Nya dan Dialah yang lebih mengetahui orang-orang yang mendapat petunjuk. (Q.S. An-Nahl (16): 125). ${ }^{29}$

Selain itu di dalam Al-Qur'an, juga terdapat banyak ajaran yang berisi prinsip-prinsip berkenaan dengan kegiatan atau usaha pendidikan itu diantaranya dalam surat Luqman ayat 12-19 yang menjelaskan mengenai prinsip-prinsip materi pendidikan yang terdiri dari masalah Iman, Akhlak, Ibadah, Sosial dan ilmu pengetahuan. ${ }^{30}$

Menurut Ahmad Ibrahim Muhanna mengatakan bahwa Al-Qur'an membahas berbagai aspek kehidupan manusia, dan pendidikan merupakan tema terpenting yang dibahasnya. Setiap ayatnya merupakan bahan baku bangunan pendidikan yang dibutuhkan setiap manusia. Meskipun demikian hubungan ayat-

\footnotetext{
${ }^{28}$ Tim Penyusun, Ilmu Pendidikan Islam (Jakarta: Proyek Pembinaan Perguruan Tinggi Agama, 1982), h. 19.

${ }^{29}$ Depag RI, op-cit., h. 421

${ }^{30}$ Tim Penyusun, op-cit., h. 20
} 
ayatnya dengan pendidikan tidak semuanya sama. Dengan kata lain hubungannya dengan pendidikan ada yang langsung dan ada yang tidak langsung. ${ }^{31}$

Dari beberapa keterangan di atas jelas bahwa pada dasarnya Al-Qur'an telah membahas berbagai persoalan mengenai hubungannya dengan Iman dan Syari'ah. Selain itu Al-Qur'an juga menceritakan tujuan hidup dan nilai sesuatu kegiatan atau amal saleh. Itu berarti bahwa kegiatan pendidikan harus mendukung tujuan pendidikan tersebut.

Pendidikan keluarga dalam Islam harus menggunakan Al-Qur'an sebagai sumber utama dalam merumuskan berbagai teori tentang pendidikan Islam. Dengan kata lain Pendidikan Agama Islam harus berdasarkan ayat-ayat Al-Qur'an yang penafsirannya dapat dilakukan berdasarkan ijtihad yang disesuaikan dengan perubahan dan pembaharuan. ${ }^{32}$

Selain al-Qur'an dasar pendidikan Islam lainnya adalah as-Sunnah. AsSunnah adalah perkataan, perbuatan atau pun pengakuan Rasul Allah. Yang dimaksud pengakuan itu adalah kejadian atau perbuatan orang lain yang diketahui Rasulullah dan beliau membiarkan saja kejadian atau perbuatan itu berjalan. ${ }^{33}$

Sunnah berkedudukan sebagai penjelas bagi Al-Qur'an, namun pengalaman ketaatan kepada Allah sesuai dengan ajaran Al-Qur'an sering kali sulit terlaksana tanpa penjelasannya. Karenanya, Allah memerintahkan kepada manusia untuk mentaati hasil dalam kerangka ketaatan kepada-Nya. Itulah sebabnya para ulama' memandang sunnah sebagai sumber kedua ajaran Islam setelah Al-Qur'an. ${ }^{34}$

Dalam lapangan pendidikan, sebagaimana dikemukakan Abdurrahman An-Nahlawi, sunnah mempunyai dua faedah yaitu menjelaskan sistem pendidikan Islam sebagaimana terdapat dalam Al-Qur'an dan menerangkan hal-hal rinci yang tidak terdapat di dalamnya serta menggariskan metode-metode pendidikan yang dapat dipraktikkan. ${ }^{35}$ Sedangkan hadis yang berhubungan dengan dasar Pendidikan Agama adalah:

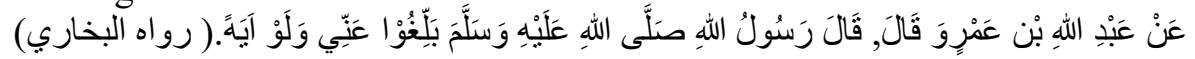
Artinya:

Dari Abdullah bin Amru berkata: Rosulullah saw. Bersabda:

"Sampaikanlah ajaranku kepada orang lain, walaupun hanya sedikit". (Diriwatkan oleh Bukhari) $^{36}$

Hadis tersebut di atas memberikan pengertian bahwa dalam ajaran Islam memang ada perintah mengenai pendidikan agama, baik pada keluarganya maupun kepada orang lain sesuai dengan kemampuannya (walaupun hanya sedikit). Banyak tindakan mendidik yang telah dicontohkan Rasulullah dalam

\footnotetext{
${ }^{31}$ Hery Noer Aly, op-cit., h. 38-39

${ }^{32}$ Tim Penyusun, op-cit., h. 20.

${ }^{33}$ Ibid., h. 20.

${ }^{34}$ Hery Noer Aly, op-cit., h. 40-41

${ }^{35}$ Ibid., h. 43

${ }^{36}$ Salim Bahreisj, Tarjamah Riyadhus Shalihin II, (Bandung: Al-Ma'arif, 1987), h. 316.
} 
pergaulannya bersama para sahabatnya. Beliau menganjurkan agar pembicaraan yang diarahkan kepada orang lain hendaknya disesuaikan dengan tingkat kemampuan berfikir mereka. Beliau memperhatikan setiap orang sesuai dengan sifatnya: laki-laki atau perempuan, tua maupun muda dan lain-lain. ${ }^{37}$ Selain itu sunnah juga berisi Aqidah dan Syari'ah. Sunnah berisi petunjuk (pedoman) untuk kemaslahatan hidup manusia dalam segala aspeknya serta untuk membina umat menjadi guru dan pendidik utama.

Jadi, sunnah merupakan landasan kedua bagi cara pembinaan pribadi manusia muslim. Sunnah selalu membuka kemungkinan penafsiran untuk berkembang. Itulah sebabnya mengapa ijtihad perlu ditingkatkan dalam memahaminya termasuk sunnah yang berkaitan dengan pendidikan. Upaya ini juga dilakukan oleh Ki Hajar Dewantara dalam menulis buku terkait pendidikan Islam sebagai bagian dari proses berfikirnya.

Menurut Ki Hajar Dewantara pendidikan umumnya berarti daya upaya untuk memajukan bertumbuhnya budi pekerti (kekuatan batin, karakter), pikiran (intellect) dan tubuh anak. Dalam pengertian taman siswa tidak boleh dipisahkan bagian-bagian itu, agar dapat memajukan kesempurnaan hidup, yakni kehidupan dan penghidupan anak-anak yang kita didik selaras dengan dunianya. ${ }^{38}$

Kendati tidak mendasarkan pada al-Qur'an dan Hadis sebagai landasan pemikirannya namun konsep pendidikan menurut Ki Hajar Dewantara ini sesuai dengan konsep pendidikan humanistik. Pendidikan (Islam) humanistik adalah pendidikan yang mampu memperkenalkan apresiasinya yang tinggi kepada manusia sebagai makhluk Allah yang mulia dan bebas serta dalam batas-batas eksistansinya yang hakiki, dan juga khalifatullah. Dengan demikian, pendidikan (Islam) humanistik bertujuan membentuk insan manusia yang memiliki kesadaran, kebebasan, dan tanggung jawab sebagai insan manusia individual, tetapi tetap bertanggung jawab terhadap lingkungan masyarakatnya sebagaimana ditegaskan pula oleh Zakiah Daradjat dan Ki Hajar Dewantara.

Jika dianalisis pandangan Zakiah Daradjat dan Ki Hajar Dewantara tentang pendidikan keluarga yang sudah dikemukakan di atas pada dasarnya adalah sama. Karena hanya berbeda dalam segi redaksi, namun essensiyang dikandungnya sama.

Sebagaimana dikemukakan Zakiah Daradjat di dalam lingkungan keluarga merupakan lingkungan pendidikan yang pertama dan utama, karena dalam keluarga inilah anak mendapatkan pendidikan dan bimbingan. Di samping itu keluarga merupakan wadah pertama dan utama bagi pertumbuhan dan perkembangan anak. Jika suasana dalam keluarga itu baik dan menyenangkan, maka anak akan tumbuh dengan baik pula. Jika tidak, tentu akan terhambatlah

\footnotetext{
${ }^{37}$ Hery Noer Aly, op-cit., h. 44.

${ }^{38} \mathrm{Ki}$ Hajar Dewantara, Karya Ki Hajar Dewantara Bagian Pertama: Pendidikan,
} (Yogyakarta: Majelis Luhur Persatuan Taman Siswa, 2004), h. 14-15. 
pertumbuhan anak tersebut. Sehingga pendidikan yang paling banyak diterima oleh anak adalah keluarga. ${ }^{39}$

Menurut Ki Hajar Dewantara pendidikan keluarga itu adalah suatu tempat yang sebaik-baiknya untuk melakukan pendidikan sosial, sehingga bolehlah dikatakan bahwa keluarga itulah tempat pendidikan yang lebih sempurna sifat dan wujudnya daripada pusat lain-lainnya, untuk melangsungkan pendidikan kearah kecerdasan budi pekerti (pembentukan watak individual) dan sebagai persediaan hidup kemasyarakatan. ${ }^{40}$

Pendapat di atas difahami bahwa pendidikan keluarga merupakan tanggungjawab orang tua kepada anak. Anak merupakan amanah dari Allah SWT. yang harus dijaga, dirawat, dan diperhatikan segala kebutuhannya, baik kebutuhan jasmani atau rohani. Adanya tanggung jawab orang tua kepada anaknya di karenakan adanya sifat lemah pada diri anak. Anak lahir dalam kondisi serba tidak berdaya, belum mengerti apa-apa dan belum dapat menolong dirinya sendiri. Ia memerlukan tempat bergantung. Tidak ada tempat bergantung yang aman sesuai kodratnya sebagai anak, kecuali kepada orang yang sangat menyayanginya yaitu kedua orang tuanya.

Selain terdapat adanya kesamaan pendapat Zakiah Daradjat dan Ki Hajar Dewantara sebagaimana dibahas pada point sebelumnya tampaknya terdapat pula perbedaan dari keduanya adalah dari konsep pendidikan keluarga. Perbedaan dari pemikiran keduanya dari konsep pendidikan dalam keluarga dengan ciri khasnya yaitu konsep pendidikan Zakiah Daradjat memasukkan aspek nilai agama dalam konsep pendidikan keluarga. Sedangkan konsep pendidikan keluarga Ki Hajar Dewantara lebih banyak memasukkan unsur teori psikologis dalam pendidikan keluarga.

Untuk lebih jelasnya pembahasan tentang persamaan dan perbedaan konsep pendidikan keluarga antara Zakiah Daradjat dan Ki Hajar Dewantara penulis tampilkan dalam bentuk skema berikut ini:

Tabel: 1

Skema Konstruk Berfikir Tokoh tentang Persamaan dan Perbedaan Pemikiran tentang Pendidikan Keluarga

\begin{tabular}{|c|l|l|}
\hline Aspek & \multicolumn{1}{|c|}{ Zakiah Daradjat } & \multicolumn{1}{|c|}{ Ki Hajar Dewantara } \\
\hline Persamaan & $\begin{array}{l}\text { Kedudukan pendidikan } \\
\text { keluarga amat penting } \\
\text { sebagai pendidikan yang } \\
\text { pertama dan utama, karena } \\
\text { dalam keluarga inilah anak } \\
\text { mendapatkan pendidikan dan } \\
\text { bimbingan. Di samping itu } \\
\text { keluarga merupakan wadah }\end{array}$ & $\begin{array}{l}\text { Keduarga penting sebagai } \\
\text { kelusat pendidikan, yang } \\
\text { berarti menuntut adanya } \\
\text { berbagai pendidikan baik } \\
\text { pendidikan individual } \\
\text { maupun sosial bagi anak } \\
\text { di keluarga. L embaga }\end{array}$ \\
\hline
\end{tabular}

${ }^{39}$ Zakiah Daradjat, Pendidikan Islam dalam Keluarga dan Sekolah (Jakarta: Ruhama, 1995), h. 47.

${ }^{40} \mathrm{Ki}$ Hajar Dewantara, Bagian Pertama Pendidikan, (Yogyakarta: Majelis Luhur Taman Siswa Cet II, 1977), h. 374. 


\begin{tabular}{|l|l|l|}
\hline & $\begin{array}{l}\text { pertama dan utama bagi } \\
\text { pertumbuhan dan } \\
\text { perkembangan anak }\end{array}$ & $\begin{array}{l}\text { pendidikan lain berfungsi } \\
\text { pelengkap dan pendorong } \\
\text { jalannya pendidikan } \\
\text { keluarga }\end{array}$ \\
\hline Perbedaan & $\begin{array}{l}\text { Memasukkan aspek nilai } \\
\text { agama dalam konsep } \\
\text { pendidikan keluarga yang } \\
\text { bersumber dari al-Qur'an } \\
\text { dan As-sunah sehingga } \\
\text { menjadi salah satu konsep } \\
\text { pengembangan pendidikan } \\
\text { Islam }\end{array}$ & $\begin{array}{l}\text { unsur teori psikologis } \\
\text { dalam pendidikan keluarga } \\
\text { yang bersumber dari nilai } \\
\text { budaya dan menjadi salah } \\
\text { satu acuan dalam } \\
\text { pengembangan pendidikan } \\
\text { nasional }\end{array}$ \\
\hline
\end{tabular}

Tabel tersebut menunjukkan adanya persamaan pemikiran Zakiah Daradjat dan Ki Hajar Dewantara yang memposisikan pendidikan keluarga sebagai pusat pendidikan. Menurut Zakiah Daradjat bahwa keluarga merupakan lingkungan pendidikan yang pertama dan utama, karena dalam keluarga inilah anak mendapatkan pendidikan dan bimbingan. Di samping itu keluarga merupakan wadah pertama dan utama bagi pertumbuhan dan perkembangan anak. Sama halnya dengan Ki Hajar Dewantara yang memposisikan keluarga sebagai pusat pendidikan, yang berarti menuntut adanya berbagai pendidikan baik pendidikan individual maupun pendidikan sosial bagi anak dilakukan dalam lingkungan keluarga. Sedangkan lembaga pendidikan lain berfungsi sebagai pelengkap dan pendorong bagi jalannya pendidikan keluarga.

Adapun perbedaan dari pemikiran keduanya dari konsep pendidikan dalam keluarga dengan ciri khasnya yaitu konsep pendidikan Zakiah Daradjat memasukkan aspek nilai agama dalam konsep pendidikan keluarga. Sedangkan konsep pendidikan keluarga Ki Hajar Dewantara lebih banyak memasukkan unsur teori psikologis dalam pendidikan keluarga.

\section{E. Penutup}

Mencermati hasil pembahasan pada bab sebelumnya dapat dikemukakan kesimpulan penelitian ini yaitu: Konsep pendidikan keluarga Zakiah Daradjat yaitu menekanakan pada makna pendidikan, tujuan pendidikan, pendidik dan peserta didik dalam pendidikan serta alat dan lingkungan pendidikan dilihat dari sudut pandang agama Islam khususnya aspek kejiwaan yang menjadi penting khususnya dalam penanaman ibadah dan akhlak oleh orang tua kepada anaknya. Konsep pendidikan keluarga Ki Hajar Dewantara juga menekankan pada komponen pendidikan nasional yang terdiri atas pengertian pendidikan, tujuan pendidikan, pendidik dan peserta didik dalam pendidikan serta alat dan lingkungan. Komponen pendidikan tersebut dilihat dari sudut pandang pembudayaan dan psikologi dalam penerapannya di lingkungan keluarga pada individu atau anak bangsa. Kesamaan dan perbedaan antara pemikiran Zakiah Daradjat dan Ki Hajar Dewantara. Persamaan dari keduanya adalah dari aspek tujuan pendidikan dan hakikat pendidikan dalam keluarga perbedaan dari keduanya adalah dari konsep pendidikan keluarga. Perbedaan dari pemikiran keduanya dari konsep pendidikan dalam keluarga dengan ciri khasnya yaitu 
konsep pendidikan Zakiah Daradjat memasukkan aspek nilai agama dalam konsep pendidikan keluarga. Sedangkan konsep pendidikan keluarga Ki Hajar Dewantara lebih banyak memasukkan unsur teori psikologis dalam pendidikan keluarga.

Implikasi pemikiran Ki Hajar Dewantara adalah kendati pun banyak menekankan pada pendidikan keluarga namun gagasan dan perjalanan hidupnya benar-benar diwarnai perjuangan dan pengabdian demi kepentingan bangsanya. Hal ini mengingat keluarga sebagai pusat pendidikan, yang berarti menuntut adanya berbagai pendidikan baik pendidikan individual maupun pendidikan sosial bagi anak dilakukan di dalam lingkungan keluarga. Bukti pentingnya konsep pendidikan Ki Hajar Dewantara hingga sosoknya dikenal sangat identik dengan pendidikan di Indonesia dan dikenal sebagai Bapak Pendidikan Nasional. Hari lahirnya diperingati sebagai Hari Pendidikan Nasional. Ajarannya pun dipakai hingga saat ini oleh Departemen Pendidikan yaitu tut wuri handayani, ing madya mangun karsa, ing ngarsa sung tulada (di belakang memberi dorongan, di tengah menciptakan peluang untuk berprakarsa, di depan memberi teladan). Implikasi konsep pendidikan Zakiah Daradjat khususnya di bidang pendidikan agama mempengaruhi wajah sistem pendidikan di Indonesia. Pembaharuan monumental yang sampai sekarang masih terasa pengaruhnya adalah keluarnya SKB Tiga Menteri (Menteri Agama, Mendikbud, dan Mendagri) pada tahun 1975, yaitu sewaktu jabatan Menteri Agama diduduki oleh Mukti Ali. Melalui surat keputusan tersebut Zakiah menginginkan peningkatan penghargaan terhadap status madrasah, salah satunya dengan memberikan pengetahuan umum 70 persen dan pengetahuan agama 30 persen. Aturan yang kemudian dilanjutkan dengan menjadikan madrasah sebagai pendidikan berciri khas Islam yang hingga kini memungkinkan lulusan madrasah diterima di perguruan tinggi umum. Konsep pendidikan yang dimilikinya diupayakan melalui Peningkatan mutu Pengelolan (administrasi) dan akademik madrasah-madrasah yang ada di Indonesia sehingga mulai munculah apa yang disebut sebagai Madrasah Model.

Rekomendasi: Kementerian Pendidikan dan Kebudayaan segera mensosialisasikan ajaran KI Hajar Dewantara yang hingga saat ini dijadikan sebagai jargon yaitu tut wuri handayani, ing madya mangun karsa, ing ngarsa sung tulada dalam bentuk seminar, lokakarya, penelitian ilmiah, buku, atau film dokumenter bidang pendidikan. Kementerian Agama segera mengembangkan konsep pendidikan keluarga dalam program pendidikan Islam di madrasah dan pesantren untuk menguatkan keterlibatan orang tua melalui paguyuban orang tua maupun komite sekolah yang akhir-akhir ini sedang digalakkan di lingkungan Kementerian Pendidikan dan Kebudayaan. 


\section{DAFTAR PUSTAKA}

Abdullah As Sahim bin Muhammad, Keesalahan Mendidik Anak Cara Islam Memperbaikinya, Yogyakarta: Media Hidayah, 1996.

Abdurahman An-Nawawi, Pendidikan Islam Di Rumah, Sekolah dan Masyarakat, Terj. Shihabuddin, Jakarta: Gema Insani Press, 1996.

Abu Ahmadi dan Nur Uhbiyati, Ilmu Pendidikan, Jakarta: Rineka Cipta, 2007.

Departemen Agama, Al-Qur'an dan Tafsir, Jakarta: Lentera Abadi, 2010.

Departemen Agama, Al-Qur'an dan Terjemahnya, Surakarta, Tiga Serangkai, 2007.

Dewantara, Ki Hajar, Pendidikan: Bagian I, Yogyakarta: Majelis Luhur Persatuan Taman Siswa, Cet. III; 2011.

, Kebudayaan: Bagian II, Yogyakarta: Majelis Luhur Persatuan Taman Siswa, Cet. III; 2011.

Ahid Nur, Pendidikan Keluarga dalam Perspektif Islam, Yogyakarta: Pustaka Belajar, 2010

Alwi Shihab, Membendung Arus: Respon Gerakan Muhamadiyah terhadap Penetrasi Misi Kristen di Indonesia, Bandung: Mizan, 1998.

Bakri Yusuf Banawi, Pembinaan Kehidupan Beragama Kehidupan Islam Pada Anak, Semarang: Dina Utama, 1993.

Basri Hasan, Keluarga Sakinah Tinjauan Psikologi dan Agama, Yogyakarta: Pustaka Pelajar, 2004.

Bil Qisthi Aqil, Keutamaan Berbakti Kepada Orang Tua, Surabaya, Mulia Jaya, 2012.

Bogdan, Robert dan Steven J. Tailor. Dasar-Dasar Penelitian Kualitatif. terj. A. Khosin Afandi, Surabaya: Usaha Nasional, 2003.

Buseri Kamrani, Pendidikan Keluarga dalam Islam dan Gagasan Implementasi, Banjarmasin Kalimantan Selatan: Lanting Media Aksara, 2010.

Daradjat, Zakiah, Islam dan Kesehatan Mental, Gunung Agung, 1982.

, Kesehatan Mental, Jakarta: Gunung Agung, 1978.

, Metodologi Pengajaran Agama Islam, Jakarta: Bumi Aksara, 1996.

, Pendidikan Islam dalam Keluarga dan Sekolah. Bandung, Remaja Rosdakarya, 1995.

Hadaru, Nawawi, Metode Penelitian Bidang Sosial, Yogyakarta, Gajah Mada University Press, 2003.

Jhon M. Echols dan Hasan Shadily, Kamus Inggris Indonesia, Jakarta: Gramedia Pustaka Utama, 2004.

Jujun S. Surya Sumantri, Filsafat Ilmu, Jakarta: Sinar Harapan, 2010. 
Khoiruddin, Sosiologi Keluarga, Jogjakarta: Nur Cahaya, 1985.

Kronik, dalam Majalah Pusara, Yogyakarta: TS No 1988

Mantep Miharso, Pendidikan Keluarga Qur'ani, Yogyakarta: Safiria Insani Press, 2004.

Masri Sinarimbun dn Sifyan Efendi, Metode Penelitian Survei, Jakarta: LP3ES, 1982.

M. Dagun Save, Psikologi Keluarga. Peranan Ayah dalam Keluarga, Jakarta: Rineka Cipta, 1990.

Miles, Mathew B. and A. Michael Huberman, Qualitative Data Analysis, London: Sage Publication, Inc, 1984.

Muhamad Arifin, Ilmu Pendidikan Islam, Suatu Tinjuan Teoritis dan Praktis Berdasarkan Pendekatan Interdisipliner, Jakarta: Bumi Aksara, 1996.

Muhtar dan Erna Widodo, Kontruksi Kearah Penelitian Deskreptif, Yogyakarta: Auyrous, 2000.

Abudin Nata, Tokoh-tokoh Pembaharuan Pendidikan Islam di Indonesia, Jakarta: Raja Gravindo, 2005.

Nashih Ulwan Abdullah, Pemeliharaan Kesehatan Jiwa Anak, Remaja Rosdakarya, Bandung, 1996.

Rahardjo Suparto, Ki Hadjar Dewantara Biografi singkat 1889-1959, Yogyakarta: Garasi 2010.

Ramayulis, Ilmu Pendidikan Islam, Jakarta: Kalam Mulia, 1994

Ratih Ni S.I, Ki Hajar Dewantara dalam Pendangan Para Cantrik dan Mentriknya, Yogyakarta: MLPTS, 1989.

Ridwan, Kekerasan Berbasis Gender, Yogyakarta: Fajar Pusta, 2006

S Rahman Hibana, Konsep Dasar Pendidikan Anak Usia Dini, Yogyakarta: PGTKI 2002.

Salam Lubis, Menuju Keluarga Sakinah, Surabaya: Terbit Terang, 2012.

Sardi Mardin, Pendidikan Manusia, Bandung: Almuni, 1985.

Setiawan Beni, Manifesto Pendidikan di Indonesia, Yogyakarta: Ar Ruzz, 2006.

Soerjono Soekanto, Sosiologi Keluarga tentang Ihwal Keluarga, Jakarta: Rineka Cipta, 1992.

Sutrisno Hadi, Metodologi Research, Yogyakarta: Andi Offset, 1990.

Suharsimi Arikunto, Prosedur Penelitian: Suatu Pendekatan Praktek, Jakarta: Rineka, 1992.

Sukawati Dewantara Bambang, Ki Hadjar Dewantara Ayahku, Jakarta: Pustaka Sinar harapan, 1989. 
Suratman, Ki Hadjar Dewantara Peletak Dasar Pendidikan Nasional, Ki hadjar Dewantara dalam Pandangan cantrik dan Matriknya,Yogyakarta: MLPTS, 1989.

Soeratman Ki, Peringatan 70 Tahun Taman Siswa, Yogyakarta: MLTPS, 1989.

Suparto Rahardjo, Ki Hajar Dewantara Biografi Singkat 1889-1959, Yogyakarta: Garasi House of Book, 2009.

Sutejo Brajanegara, Sejarah Pendidikan Indonesia, Yogyakarta: Badan Konggres Pendidikan Indonesia, 1956.

Syaiful Bahri Djamarah, Pola Komunikasi Orang tua dan Anak dalam Keluarga (sebuah Perspektif Pendidikan Islam), Jakarta: Rineka Cipta, 2004.

Syaodih, Nana Sukadinata, Metode Penelitian Pendidikan, Bandung: Remaja Rosdakarya, 2007

Syamsu yusuf, Psikologi Perkembangan Anak dan Remaja, Bandung: Remaja Rosda Karya, 2002.

Takariawan Cahyadi, Pernak-Pernik Rumah Tangga Islam Tatanan dan Peranannya dalam Masyarakat, Surakarta: Era Edicitra Intermedia, 2011.

Thabib Chabib, Kapita Selekta Pendidikan Islam, Yogyakarta: Pustaka Pelajar, 1996.

T Me Very Ruth, Taman Siswa dan Kebangsaan Nasional, Taman Siswa dalam Perspektif Sejarah dan Perubahan, Yogyakarta: MLTPS.

M. Tauchid, Perjuangan dan Ajaran Hidup Ki Hadjar Dewantara,Yogyakarta: MLPTS, 1963.

TM. Hasbi As Siddiqey, Filsafat Hukum Islam, Jakarta: Bulan Bintang, 1986. 